\title{
Ottawa erases legal basis for refugee care
}

$\mathrm{W}$ hen a Federal Court judge ordered Ottawa to reverse deep cuts to refugee health care in July 2014, the government appealed. But then, rather than waiting for an appeal court decision, the federal Cabinet quietly eradicated the program's legal basis early in November 2014 . The move was only recently discovered by the refugee lawyers who argued the case on behalf of more than 100000 refugee applicants.

"It was done completely in secret," says Pia Zambelli, a Montréal-based refugee lawyer. "We only found out about it by accident."

At issue, explains Zambelli, is the Cabinet order - known as Order in Council P.C. 157-11/848 of June 20, 1957 - that first committed Ottawa to begin financing the refugee health care program almost 60 years ago. In 2012, when the Cabinet slashed health care for failed refugee claimants as well as for claimants from countries Canada deems safe, it repealed the Order in Council that created it.

The government's actions triggered Zambelli and other refugee lawyers to successfully sue and in July 2014, Federal Court Justice Anne Mactavish ordered Ottawa to fully restore refugee health care by Nov. 4, 2014.

In the court judgment and reasons, a government spokesperson states that "Canadians have been clear that they do not want illegal immigrants and bogus refugee claimants receiving gold-plated health care benefits that are better than those Canadian taxpayers receive. Our Government has listened and acted."

Just two days after the federal government complied with Mactavish's order, as Zambelli recently discovered, the Cabinet quietly repealed the 1957 Order in Council a second time. This was done despite the Court order instructing the government to fully reinstate the program the Order in Council spawned. And that, Zambelli says, amounts to a pre-emptive, preju-

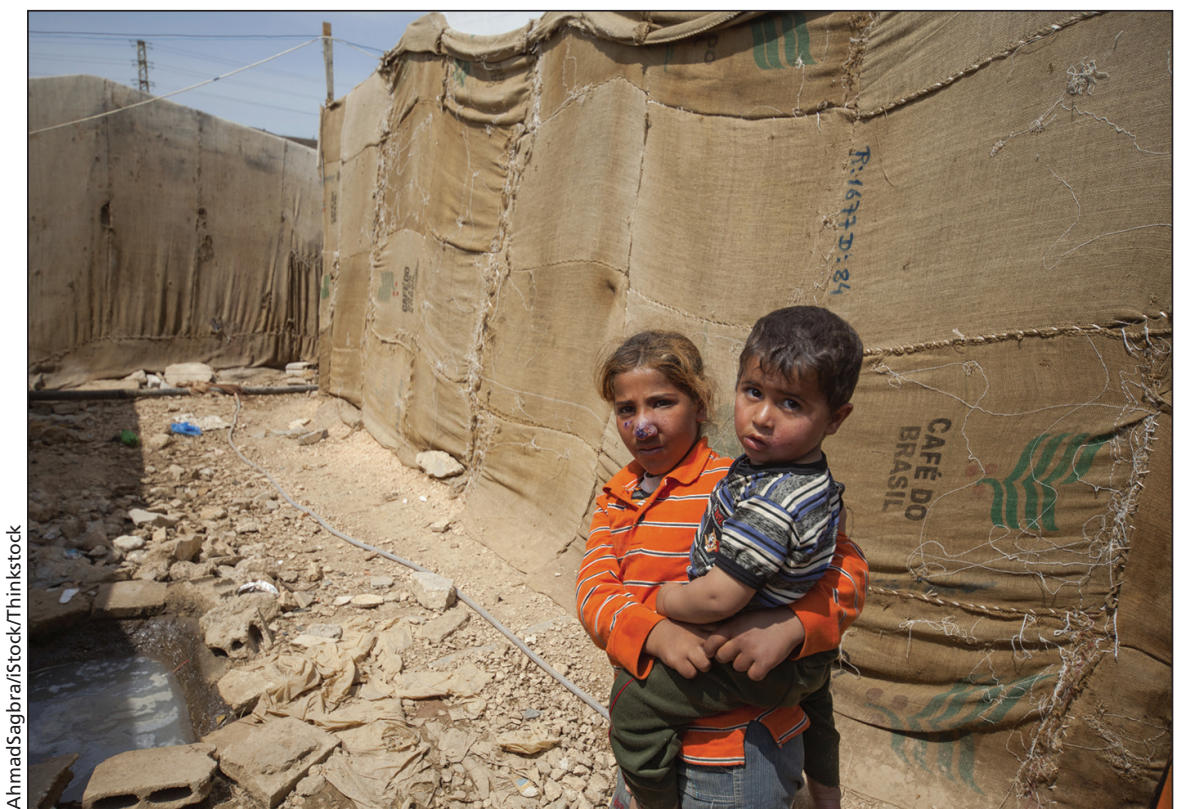

Health care for refugees, such as these Syrian children, was slashed by the Canadian government, then restored by a court order that is now under appeal.

dicial strike ahead of Ottawa's effort to appeal Mactavish's decision.

"It was expressly the intention of the Court to reinvigorate the 1957 [Order in Council]," Zambelli says. "That is the remedy the Court assumed it was providing. Now the rug has been pulled out from under that."

Human rights lawyers and refugee health care providers say they are worried by the Cabinet's renewed attack on the refugee health care program even while the issue remains before the courts.

Justice Mactavish's ruling debunked the government's claim that it was cutting refugee health care in the interests of fairness and cost-savings. But now, "the government simply disappeared the program that the Court had just ordered it to reinstate," says Janet Cleveland, a McGill University-based lawyer and psychologist who heads a study probing the impacts of the government's cuts to refugee health care. "They appear to have decided to simply abolish federal coverage for refugee health care."

Citizenship and Immigration Minister Christopher Alexander declined a request from $C M A J$ to discuss the fed- eral Cabinet's actions. Instead, Citizenship and Immigration Canada spokeswoman Julie Lafortune explained in written responses to questions that the 1957 Order in Council was repealed when the 2012 cuts were implemented for the "benefit of Canadian taxpayers and genuine refugees alike."

The decision to repeal it a second time - despite the court's finding that the government was unable to demonstrate any benefits to taxpayers or refugees from the cuts - was done "to ensure full clarity," Lafortune added.

For now, says Lafortune, "there are no implications for refugee claimants as a result of repealing the 1957 Order in Council. Eligible beneficiaries continue to receive health care coverage."

What the government's tactics portend for the future is unclear, says Maureen Silcoff, a Toronto-based lawyer working with Zambelli to prepare for a Jan. 27 hearing at which they will charge the government with failing to fully restore refugee health care. Silcoff believes that "whether the program is based on the 1957 Order in Council or any other means, in my view not hav- 
ing an Order in Council doesn't release the government from its obligation to fund refugee health care."

Audrey Macklin, a University of Toronto specialist in human rights law, agrees with Zambelli and Cleveland that the government's tactics seem aimed at erasing refugee health care as we once knew it, no matter what the courts ultimately decree.

"I'm not sure whether it is even lawful to retroactively repeal something," Macklin argues, "but in any case, what it means is that if what they are doing now does not comply with the court's ruling, there is no prior system to which it can revert, because it repealed the [Order in Council] that created it." Nav Persaud and Paul Webster, Toronto

CMAJ 2015. DOI:10.1503/cmaj.109-4979 